\title{
Correlation between the diversity of xenobiotic catabolism genes in Rhodococcus and phytotoxicity of imidazolinone and organophosphate herbicide biotransformation products \\ Kruglova M.N., Chugunova Y.A., Samkov A.A., Volchenko N.N., Khudokormov A.A. Kuban State University, Krasnodar, Russia \\ E-mail: mariya-kruglova-98@mail.ru
}

Key message. Rhodococcus strains with a wide spectrum of catabolic genes, have provided a more marked reduction of toxicity of imidazolinone. In the case of glyphosate, the opposite strain-specific pattern is found.

Keywords: Rhodococcus, herbicides, imazamox, imazapyr, glyphosate

One of the problems of our time is chemical contamination of the biosphere with herbicides, which remain the most effective and cost-effective way to increase yields. Microorganisms, in particular, actinobacteria of the genus Rhodococcus, which are characterized by a variety of catabolic pathways, can play an important role in biological detoxification of soil and water. The aim of the work was to identify the relationship between the presence of key catabolic genes, responsible for the degradation of pesticides, and the level of toxicity of a set of biotransformation products of organophosphorus herbicides and imidazolinones by representatives of the genus Rhodococcus, in comparison with the initial substances.

All used strains were able to grow on the selected pesticides. Determination of the presence of catabolic genes $-A t z A, A t z B$, AtzC, amoA, akbA, npcB, bphA associated with pesticide degradation in strains of Rhodococcus erythropolis $\mathrm{B} 2$, Rhodococcus spp. F2 and J8 were performed via PCR. To assess the phytotoxicity of the decomposition products of herbicides, the strains were cultivated in a liquid mineral medium with imazamox, imazapir, and glyphosate. Beta vulgaris seeds were treated with supernatants of liquid cultures containing microbial degradation products, as well as solutions of the original pesticides.

It was found that the biotransformation products of all the studied herbicides have a rather high level of inhibition of the growth of the root system of seedlings, the phytoeffect indicators exceed $60 \%$, but the negative impact of the initial herbicides is much higher. The strain Rhodococcus sp. J8, which did not have any of the studied catabolic genes, showed the greatest effect of inhibiting the growth of the root system by the products of imidazolinone degradation by this strain, which could be associated with large residual concentrations of the original substance. Metabolites of glyphosate transformation by the Rhodococcus sp. F2 with the $A t z B, A t z C$, and $n p c B$ genes, as well as the presumed homologue of the AtzA gene, were the least toxic to the test plant. Rhodococcus erythropolis $\mathrm{B} 2$ is presumed to have the AtzA gene and the $n p c B$ gene homolog. The products of imidazolinone biodegradation with this strain had the least effect of inhibiting of the root system, in the case of glyphosate - the greatest.

\section{Взаимосвязь между разнообразием генов катаболизма ксенобиотиков у родококков и фитотоксичностью продуктов биотрансформации имидазолинонов и фосфорорганических гербицидов Круглова М. Н., Чугунова Ю. А., Самков А. А., Волченко Н. Н., Худокормов А.А. ФГБОУ ВО «Кубанский государственный университет», Краснодар, Россия}

Аннотация. Штаммы родококков, обладающие широким спектром катаболических генов, обеспечили более
выраженное снижение токсичности имидазолинонов. B случае глифосата, итаммоспецифично обнаружена противоположная картина.

Ключевые слова: Rhodocoсcus, гербицидь, имазамокс, имазапир, глифосат

Одной из проблем современности является химическое загрязнение биосферы гербицидами, которые остаются наиболее эффективным и экономически выгодным способом повышения урожайности. Важную роль в биологической детоксикации и деконтаминации почв и воды могут играть микроорганизмы, в частности, актинобактерии рода Rhodococcus, которые характеризуются разнообразием катаболических путей. Целью работы было выявление у представителей рода Rhodococcus взаимосвязи между наличием ключевых катаболических генов, ответственных за деградацию пестицидов, и уровнем токсичности набора продуктов биотрансформации фосфорорганических гербицидов и гербицидов ряда имидазолинонов, по сравнению с исходными веществами.

Все исследованные штаммы были способны к росту на выбранных пестицидах. Определение наличия катаболических генов - AtzA, AtzB, AtzC, amoA, akbA, npcB, bphA, связанных с деградацией пестицидов, у штаммов Rhodococcus erythropolis B2, Rhodococcus spp. F2 и J8 проводили при помощи ПЦР. Для оценки фитотоксичности продуктов разложения гербицидов штаммы культивировали на жидкой минеральной среде, где источником углерода и энергии являлись имазамокс, имазапир и глифосат. Семена Beta vulgaris обрабатывали супернатантами жидких культур, содержащих продукты микробного распада, а также растворы исходных пестицидов.

Обнаружено, что продукты распада всех исследованных гербицидов оказывают довольно высокий уровень торможения роста корневой системы проростков, показатели фитоэффекта превышают 60 \%, но при этом негативное влияние самих гербицидов значительно выше. Штамм Rhodococcus sp. J8, у которого не было обнаружено ни одного из исследованных генов, показал наибольший эффект торможения роста корневой системы продуктами деградации имидазолинонов данным штаммом, что могло быть связано с большими остаточными концентрациями исходного вещества. Метаболиты трансформации глифосата штаммом Rhodococcus sp. F2, обладающим генами $A t z B, A t z C, n p c B$, a также предположительно гомологом гена $A t z A$, были наименее токсичными в отношении тест-растения. Rhodococcus erythropolis В2, предположительно, имеет ген AtzA и гомолог гена прсB. Продукты разложения имидазолинонов данным штаммом оказывали наименьший эффект торможения корневой системы, в случае глифосата - наибольший. 